\title{
Plant traits that influence flower visits by birds in a montane forest
}

\author{
Oscar Gonzalez \\ Grupo Aves del Peru. Gomez del Carpio 135 Lima, Peru \\ and \\ Department of Natural Sciences, Emmanuel College, Franklin Springs 30662 GA, USA. \\ ogonzalez@ec.edu
}

Abstract

In a bird-flowering plant network, birds select plants that present traits attractive to them. I studied plant characteristics that might predict flower visitation rate by the most common bird visitors in a bird-flowering plant network located in an elfin forest of the Andes. The nectarivorous birds which had the highest number of interactions with

14 flowering plants in this network were the Coppery Metaltail (Metallura theresiae), the 15 Great Sapphirewing (Pterophanes cyanopterus), and the Moustached Flowerpiercer 16 (Diglossa mystacalis). I analyzed different flower traits (flower aggregation, nectar 17 volume, nectar energy, color, orientation, and dimensions of the corolla) of the common 18 plants that these birds visited with a principal component analysis. The plants most visited by birds were Brachyotum lutescens and Tristerix longebracteatus. While nectar

20 traits of the plants seemed to be the best predictor for bird visitation, there was no

21 statistical association between visitation and plant traits, except for Metallura theresiae

22 in the dry season. I discuss the possible causes of resource partitioning for these

23 nectarivorous birds.

Keywords: Nectar, elfin forest, flower traits, nectarivorous birds 
Birds that feed on nectar make decisions on multiple scales to select plants and flowers; these scales could be at habitat, flowering patch, individual plant, or flower level (Sutherland and Gass 1995; Ortiz-Pulido and Vargas-Licona 2008). The visitation of each bird species may be different for the same resource (Feinsinger 1976; Davis et al. 2015). Different plant traits can attract flower visitors, such as the color of the corolla (Wilson et al. 2006), the aggregation of flowers of the plants (Fonturbel et al. 2015), the morphological matching of the feeding apparatus with the flower (Cotton 2007), flower orientation (Aizen 2003), or nectar properties.

Nectar is a primary resource for flower visitors and is a crucial determinant in interactions between animals and plants (Wiens 1989, Rathcke 1992, Cotton 2007, Janecek et al. 2012; Justino et al. 2012). The energy resource of nectar is determined by volume present and sugar concentration; animals tend to preferentially visit flowers with the most reward (Fleming et al. 2004). It is likely that nectarivorous birds - such as hummingbirds or flowerpiercers - have specific preferences for some plants depending on the nectar volume or concentration of their flowers (Hainsworth and Wolf 1976, Nicolson and Fleming 2003, Gutierrez et al. 2004, Zambon et al. 2020), and often for amino acids (Hainsworth and Wolf 1976). Although, the best sources for amino acids in hummingbirds are insects (Abrahamczyk and Kessler 2015).

The activity of flower visitors can be predicted by flower phenology (Feinsinger 1980, Stiles 1980, Murcia 1996, Rotenberry 1990, Gutierrez and Rojas 2001, Dante et al. 2013, Magilanesi et al. 2014, Gonzalez and Loiselle 2016). For example, movements of hummingbirds are known to be associated with flower blooms (Schuchmann 1999). In temperate forests, hummingbird diversity correlates with flower density, such as in Mexico (Martinez del Rio and Eguiarte 1987), Canada (Inouye et al. 1991), and the U.S. (McKinney et al. 2012). Furthermore, seasonality in the tropics is highly influential in plants and their pollinators (Cruden et al. 1983); temperature and precipitation influence local bird activity (Bourgault et al. 2010) such as foraging time and visitation rates of hummingbirds (Fonturbel et al. 2015).

In different tropical forests, several studies have shown an association of nectarivorous birds with nectar resources. Some examples of hummingbirds and their preferences by region are as follows: In Costa Rica - breeding, molt, diversity, density, and movements with blooming of their flowers (Stiles 1978, 1985, Wolf et al. 1976); in Puerto Rico - visits to flowers depend on bill size and corolla length (Kodric-Brown et al. 1984); in Bolivia - richness with flower availability (Abrahamczyk et al. 2011); and in Colombia - life cycle with nectar energy and seasonal abundance of flowers (Gutierrez et al. 2004, Cotton 2007, Toloza-Moreno et al. 2014). However studies that looked to find a relationship between hummingbirds and nectar in a landscape gave different results (Ortiz-Pulido and Rodriguez 2011). Other nectarivorous birds may select flowers by traits other than nectar such as accessibility or inflorescence size; that is the case of African sunbirds (Schmid et al. 2015). For hummingbirds, the different foraging strategies (territorial or traplining) are also important in their floral selectivity (Feinsinger 1976).

The study of nectarivorous bird communities in the neotropics provide 71 opportunities to understand ecological interactions in different ecosystems (e.g.

72 Rodriguez-Flores et al. 2012, Maglianesi et al. 2014) and test specific hypotheses on 
the drivers of these interactions, such as morphological mismatch (Vinzentin-Bugoni et al. 2014) or nectar quality and quantity (Maruyama et al. 2014). An understudied ecosystem that has an abundant nectarivorous bird community occurs in the upper montane forest of the Andes (Ramirez et al. 2007, Gonzalez 2008). In these forests, a diverse suite of hummingbirds and flowerpiercers is abundant (Gonzalez et al. 2019). However, which factors explain the patterns of plant visitation is little known in this system. Consequently, in this study the question is: Which traits of flowering plants are associated with visits by common nectarivorous birds? I hypothesize that traits associated with energy explain flower visits better than other floral traits.

\section{4}

\section{Study Area}

This research was conducted in the elfin forest in Unchog, located in the high Andes of Peru ( $9^{\circ} 42^{\prime} 32.33^{\prime \prime}$ S, $76^{\circ} 9^{\prime} 39.13^{\prime \prime}$ W; $3700 \mathrm{~m}$ ) from 2011 to 2014 . The elfin forest is considered as an ecotone between the cloud forest and the puna grassland. It has a marked seasonality of dry (May to September) and wet periods (October to March). The dry season is not devoid of rain, but it has less rain than the wet season. The temperature is cold, colder in the dry season, and the annual range varies from - 1 to $15^{\circ} \mathrm{C}$.

The landscape in Unchog is hilly, with small forest pockets dominated by Weinmannia. The non-forested area is a matrix of puna grasslands with shrubs, the most common one being Brachyotum spp. I sampled three sites that concentrated the most extensive groves of elfin forest ( 8 ha each), embedded in an area of 300 ha. These sites ranged from 0.6 to $1.7 \mathrm{Km}$ from each other. The plant composition was very similar in the three sites (Sorensen index of similarity ranged from $0.72-0.80$ among sites), so I pooled all the information on plant traits.

\section{Study Species}

Nectarivorous birds present in the area were recorded by direct observations with binoculars. I walked inside the forest patches and forest edges, recording the birds and their visits to the flowers. I considered a visit as the moment when a bird fed on a flower or flowers of a plant, disregarding the number of flowers visited and if the visit was legitimate (pollinating) or not because this research considers the visitor's perspective. A matrix of observed interactions, accounting for the times a bird was visiting a plant was constructed (Gonzalez and Loiselle 2016, Gonzalez et al. 2019). Birds and plants of the bird-flowering plant visitation network that were more abundant and more connected were selected to examine which plant traits predict bird interactions (OrtizPulido and Vargas-Licona 2008).

The three most quantitatively important bird species that visited flowers were Coppery Metaltail (Metallura theresiae) - hereafter, the Metaltail; Great Sapphirewing (Pterophanes cyanopterus) - hereafter, the Sapphirewing, and Moustached Flowerpiercer (Diglossa mystacalis) - hereafter, the Flowerpiercer. The Metaltail is a small-billed, territorial hummingbird that weighs $5.07 \pm 0.09 \mathrm{~g}$. and has a bill length of $12.03 \pm 0.87 \mathrm{~mm}$. The Sapphirewing is a large and non-territorial hummingbird with a 
117 mass of $9.3 \pm 1.27 \mathrm{~g}$. (Dunning 2007) and a bill length of $30.06 \pm 2.78 \mathrm{~mm}$. The

118 Flowerpiercer, which was the third most abundant species in terms of flower visitations,

119 is a passerine nectar-robber with a mass of $16.2 \mathrm{~g}$. (Dunning 2007) and a bill length of

$120 \quad 10.73 \pm 1.41 \mathrm{~mm}$.

121

122 Flower Traits

I selected a subset of 13 plants that these three bird species visited to account for flower traits that might affect bird visitation. These plants had more than one interaction with birds (Gonzalez and Loiselle 2016) and were common in at least one season of the whole period of observation (Table 1). I sampled a total of 186 individual plants and an average of 14 individuals per plant species.

To account for the availability of the flowers, I graphed the availability of the flowers in the dry season of 2014 (May, June, and July) and in the wet season of 2013 (January, February, March, and April). The resulting phenology is representative of the whole sampling period. I recorded the color of the corolla of the flowers that the birds visited (white, pink, purple, green, and red) and the orientation as horizontal or pendular (Table 1).

It is known that hummingbirds in the Andes have specific preferences for some strata in forested habitats (Gutierrez-Zamora 2008); so for each of the plants, I estimated the height where the flowers were located in relation to the ground level (Fenster et al. 2015). I also estimated flowers per individual plant as a measurement of aggregation of the resource (Dudash et al. 2011), then corolla length (Maruyama et al. 2014) and opening (Temeles et al. 2002). Nectar volume and sugar amount were also considered (Stiles and Freeman 1993; Ornelas et al. 2007). The data collected was averaged by each plant species.

Table 1. Characteristics of plant species frequently visited by birds in the elfin forest.

\begin{tabular}{lllrrrrr}
\hline Plant species & $\begin{array}{l}\text { Flower } \\
\text { color }\end{array}$ & $\begin{array}{l}\text { Flower } \\
\text { orientation }\end{array}$ & $\begin{array}{r}\text { Number } \\
\text { of plants } \\
\text { sampled }\end{array}$ & $\begin{array}{l}\text { Mean } \\
\text { Height } \\
(\mathrm{m})\end{array}$ & $\begin{array}{l}\text { SD } \\
\text { Height }\end{array}$ & $\begin{array}{l}\text { Mean } \\
\text { Flowers } \\
\text { in a plant }\end{array}$ & $\begin{array}{l}\text { SD } \\
\text { Flowers a plant }\end{array}$ \\
\hline Bomarea brevis & Red & Pendular & 6 & 0.39 & 0.20 & 2.7 & 1.7 \\
Bomarea setacea & Red & Pendular & 12 & 0.40 & 0.01 & 13.6 & 7.4 \\
Brachyotum lutescens & Green & Pendular & 18 & 0.92 & 0.60 & 36.5 & 22.1 \\
Brachyotum naudinii & Purple & Pendular & 10 & 0.80 & 0.60 & 30.2 & 11.6 \\
Centropogon isabellinus & Red & Horizontal & 6 & 0.70 & 0.01 & 19.0 & 14.3 \\
Desfontainia spinosa & Red & Horizontal & 18 & 1.00 & 0.01 & 17.4 & 9.3 \\
Disterigma sp & White & Pendular & 11 & 1.00 & 0.01 & 17.4 & 11.3 \\
Fuchsia decussata & Red & Pendular & 33 & 5.47 & 2.60 & 20.6 & 11.8 \\
Gentianella fruticulosa & Red & Pendular & 9 & 0.10 & 0.09 & 11.7 & 3.4 \\
Passiflora cumbalensis & Pink & Pendular & 18 & 7.13 & 2.60 & 9.3 & 3.5 \\
Puya pseudoeryngioides & White & Horizontal & 23 & 0.65 & 0.01 & 43.5 & 20.5 \\
Rubus sp. & Purple & Horizontal & 3 & 0.23 & 0.40 & 15.2 & 13.0 \\
Tristerix longebracteatus & Red* & Horizontal & 19 & 6.1 & 5.80 & 30.5 & 18.2 \\
\hline
\end{tabular}




\section{Nectar Sampling}

Nectar characteristics were measured for these 13 plants (Table 2). Nectar volume in $\mu \mathrm{L}$ was measured with calibrated capillary tubes of $75 \mathrm{~mm}$ and the concentration in $\mathrm{g}$ of sugar per $100 \mathrm{~g}$ of solution with a refractometer that accounted for 0 to $50 \%$, brand VEE GEE $®$ (Kearns and Inouye 1993). Sugar constituents were not identified. There are several problems in measuring nectar, mostly due to its own variation within flowers of the same plant, time of day, and climatic conditions (Willmer 2011). The volume of nectar varied by the time of the day (McDade and Weeks 2004a) and even in flowers of the same plant (Cruden and Hermann 1983). Other studies involving measurements of nectar volume have confirmed its large variability (Baker 1975, Bolten et al. 1979, Ayala 1986, Stiles and Freeman 1993, Gutierrez and Rojas 2001, McDade and Weeks 2004a, b, Zambon et al. 2020); so the coefficient of variability for volume and concentration was considered in the analysis, as well as the largest amount of nectar (Opler 1983).

Table 2. Nectar characteristics of flowers visited by birds in the elfin forest measured six hours after sunrise.

\begin{tabular}{|c|c|c|c|c|c|c|}
\hline \multirow[b]{2}{*}{ Species } & \multicolumn{2}{|c|}{$\begin{array}{c}\text { Nectar } \\
\text { Volume } \\
\text { (microliters) }\end{array}$} & \multicolumn{2}{|c|}{$\begin{array}{c}\text { CC nectar } \\
\text { (gr sugar/gr } \\
\text { solution)*100 }\end{array}$} & \multicolumn{2}{|c|}{$\begin{array}{c}M g \\
\text { sugar/flower }\end{array}$} \\
\hline & Avg & SD & Avg & SD & Avg & SD \\
\hline Bomarea brevis & 3.90 & 2.21 & 9.48 & 8.34 & 0.38 & 0.19 \\
\hline Bomarea setacea & 2.80 & 2.62 & 0.50 & 0.00 & 0.01 & 0.00 \\
\hline Brachyotum lutescens & 36.39 & 16.84 & 7.74 & 5.58 & 2.90 & 0.96 \\
\hline Brachyotum naudinii & 20.40 & 14.51 & 4.60 & 0.70 & 0.96 & 0.10 \\
\hline Centropogon isabellinus & 27.76 & 10.76 & 9.00 & 3.55 & 2.59 & 0.40 \\
\hline Desfontainia spinosa & 12.41 & 5.69 & 10.44 & 5.15 & 1.35 & 0.30 \\
\hline Disterigma $s p$ & 5.90 & 0.00 & 2.50 & 0.00 & 0.15 & 0.00 \\
\hline Fuchsia decussata (DS) & 10.68 & 5.71 & 3.40 & 1.46 & 0.37 & 0.08 \\
\hline Fuchsia decussata (WS) & 22.99 & 15.94 & 12.62 & 8.5 & 3.05 & 1.40 \\
\hline Gentianella fruticulosa & 1.92 & 1.40 & 1.75 & 1.25 & 0.03 & 0.02 \\
\hline Passiflora cumbalensis (DS) & 25.56 & 15.83 & 19.54 & 5.81 & 5.39 & 0.94 \\
\hline Passiflora cumbalensis (WS) & 23.95 & 8.89 & 10.59 & 3.99 & 2.66 & 0.36 \\
\hline Puya pseudoeryngioides & 36.80 & 33.96 & 9.04 & 8.88 & 3.45 & 3.12 \\
\hline Rubus sp. & 6.02 & 3.87 & 3.19 & 1.47 & 0.19 & 0.06 \\
\hline Tristerix longebracteatus (DS) & 23.30 & 17.71 & 5.90 & 3.30 & 1.41 & 0.59 \\
\hline Tristerix longebracteatus (WS) & 20.87 & 15.31 & 4.29 & 4.52 & 0.91 & 0.70 \\
\hline
\end{tabular}

163 Avg: Average, SD: Standard Deviation, reported only for the flower that had nectar. DS:

164 Dry Season, WS: Wet Season.

I removed nectar at different times for different flowers to check which measurement best would account for the nectar available to the plant's potential flower 168 visitors. I did not use the standard procedure of bagging flowers for 24 hours because 169 there were flowers that did not produce nectar continuously, so these measurements 
170 could be misleading (Cruden and Hermann 1983; McDade and Weeks 2004a).

171 Temperatures during the night often dropped below freezing, which causes flowers to

172 produce less nectar. Furthermore, due to atmospheric cold fronts which are very

173 common in this region, flower abortion is frequent; several flowers wilted or were without nectar ("rewardless") in the early morning (59\% of 929 measurements of flowers resulted in no nectar). Flowers that were covered for 6 hours since sunrise had the lowest proportion of flowers without nectar (57\%). Hence, I selected this measurement as the most accurate and the best indicator for the offer of nectar to the birds. Other researchers, such as Handelman and Kohn (2014), also used nectar measurements in the morning (between 8 to $12 \mathrm{PM}$ ) to account for the energetic offer of the plants to hummingbirds. The standing crop (nectar mass in milligrams) for each plant species was calculated by multiplying the concentration by the volume of nectar, related by the number of hours it was covered (Cruden and Hermann 1983). Conversions were made following Dafni (1992:148).

\section{Analysis}

I analyzed characteristics of flowers available and bird visits in wet and dry seasons separately by pooling the data across months that represented the dry season (May to September) and the wet season (October to April). I used principal component analysis (PCA) to analyze the patterns of the traits of the selected plant species (Gutierrez-Zamora 2008). This analysis identified aggregation tendencies of flower morphology (corolla length and width), distribution of flowers in the plant (flower aggregation), and flower reward to visitors (nectar volume, sugar of nectar). I used the package Factomine in $\mathrm{R}$ (Le et al. 2008), which helps to analyze data with multiple variables that could be numerical, ordinal, or categorical. For each of these variables, the program calculates the correlation coefficient between them and each of the values given by the plants. In this case, I set up nectar volume, sugar amount, coefficient of variance of both corolla length, corolla wide variables as numerical. The orientation of the flower (horizontal or pendular) and flower color were considered as categorical. The replicates were each one of the 13 plant species.

These plant species were ordinated based on their floral traits, such that the dispersion of the plants in the ordination reflects their separation in floral characteristics. The relative importance of the various floral characters in separating plants along the principal coordinate axes is defined by comparing the variance of the trait in the ordination with the variance of all the traits in the plot using a T-test (Le et al. 2008).

To confirm a possible association of the visitation of each species with plants of specific characteristics, I correlated the visitation data of each bird species to the plants with each of the first two axes of the PCA ordination in the dry season and in the wet season. For the comparison of bird visitations of the Sapphirewing and the Flowerpiercer with each axis, I used Spearman's rank-order correlation due to the nonnormality of the data. The statistics was done with the package Stats in R. For the visitations of the Metaltail, I performed a generalized linear model (GLM) with a Poisson distribution (Zuur et al. 2009), using the axis of the PCA as independent variables. 


\section{Results}

\section{Principal Components of Flower Traits}

216

217

218

219

220

221

222

223

224

225

226

227

228

229

230

231

232

233

234

235

236

237

238

239

240

241

242

243

244

245

246

247

248

249

250

251

252

253

254

255

256
The two principal axes of the ordination accounted for $66 \%$ of all variation (Figure 1 and Sup. Table 1). Figure 1 shows only the dry season due to the ordination of plant traits was almost identical for both seasons. Plants that had greater energy (mg. sugar per flower, nectar per flower, maximum nectar and maximum concentration) and larger number of flowers per plant tended to cluster with higher scores on the first principal component axis (e.g. Tristerix longebracteatus, Centropogon isabellinus, Brachyotum lutescens). Plants located in higher vegetation strata - with larger corolla and wider corolla opening (this last trait becoming important only in the wet season) and few flowers per plant - tended to have higher scores along the second PCA axis (Fuchsia decussata, Desfontainia spinosa, Passiflora cumbalensis) (Figure 2). These results were largely consistent between the wet and dry seasons, even with some turnover in plant species that flowered.

The Metaltail in the dry season had almost half of its visitations to the shrub Brachyotum lutescens (Table 3), which has relatively moderate number of flowers per plant and high variability in nectar volume and sugar. The rest of their flower visits were dispersed and included plants with relatively low nectar rewards and plants that occurred in lower vegetation strata (Figure 2A). In the wet season, the Metaltail visited a greater diversity of plants as measured by their floral traits, demonstrated by their overlap in all quadrants of the ordination (Figure 2B). The Sapphirewing tended to visit plants with higher energy rewards, large corolla, and higher vegetation strata such as the mistletoe Tristerix longebracteatus, with $92 \%$ of all visits in the dry season (Figure 2C). Similarly, visits during the wet season were also concentrated on plants with these same characteristics. As in the dry season, the mistletoe dominated among plant visits (75\%) (Figure 2D). The Flowerpiercer tended to also visit plants primarily with high nectar reward and a high number of flowers per individual such as the previous mistletoe (58\% of visits) and Brachyotum lutescens (25\% of visits) in the dry season (Figure 2E). Although Brachyotum lutescens accounted for $50 \%$ of the visits in the wet season (Figure $2 \mathrm{~F}$ ), like the Metaltail, flowerpiercers visited a diversity of plants across the entire ordination space.

I found that bird visits for the Sapphirewing and the Flowerpiercer could not be explained by floral traits (Table 4). All correlations between these two birds and PCA scores for plant traits were non-significant, except for a positive correlation for the Sapphirewing along the second axis in the wet season (Table 4). However, I found a significant positive association along axis 1 and a significant negative association along axis 2 for visits by Metaltails in the dry season (Axis 1: $0.19, p<0.001$; Axis 2: $-0.17, p<$ $0.05, \mathrm{df}=12$ ) but not in the wet season. (Axis 1: $-0.04, p=0.65$; Axis 2: $0.01, p=0.92$, $\mathrm{df}=12)$ Therefore, in the dry season, Metaltails appeared to frequently visit plants with higher energy rewards (axis 1) and plants with smaller corollas located lower in the vegetation. 


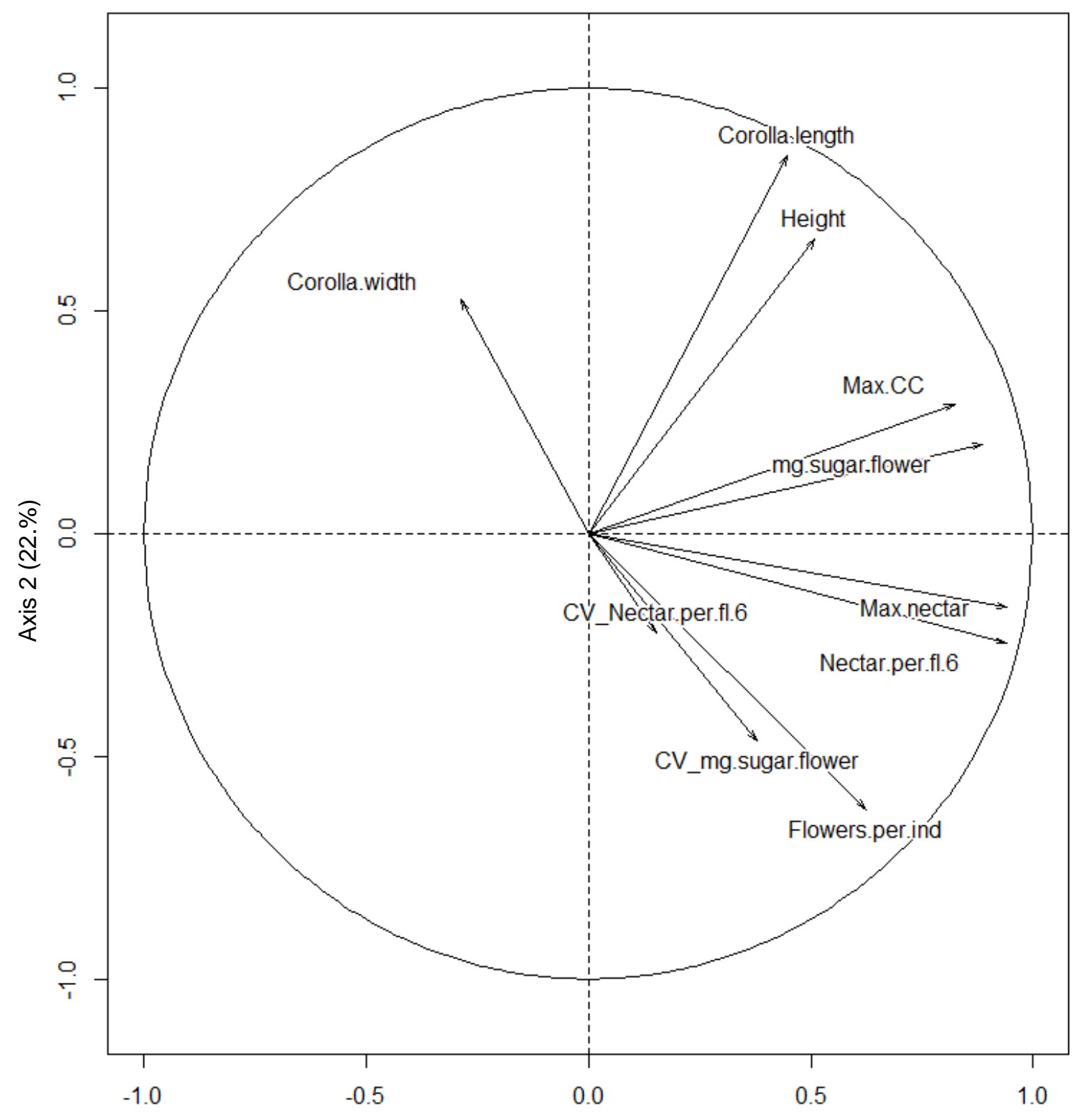

Axis 1 (43\%)

Figure 1. Principal component analysis of the plant traits that influence the visitation rate of the most connected bids in the bird-visitation network (dry season). Axis 1: Nectar amount (volume and mass), corolla length, height of the flower. Axis 2: Flower aggregation, nectar variability, corolla opening. Wet season was almost identical. 


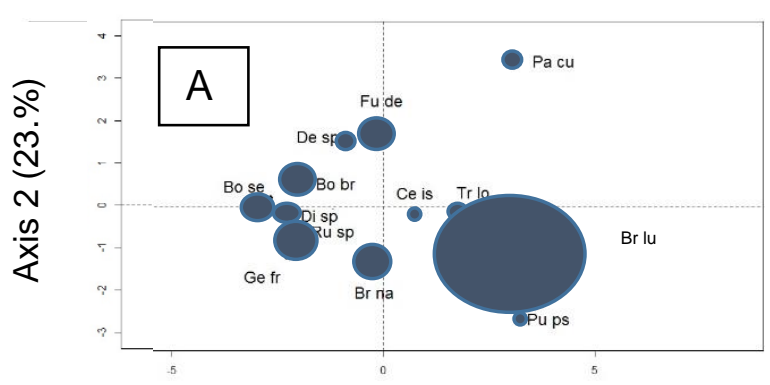

Axis 1 (43\%)

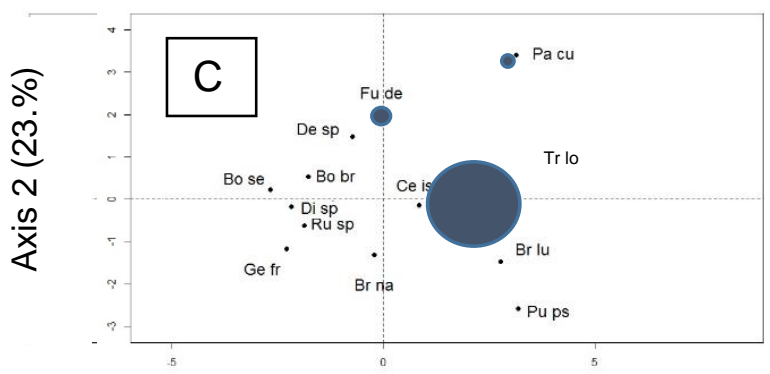

Axis $1(43 \%)$

269

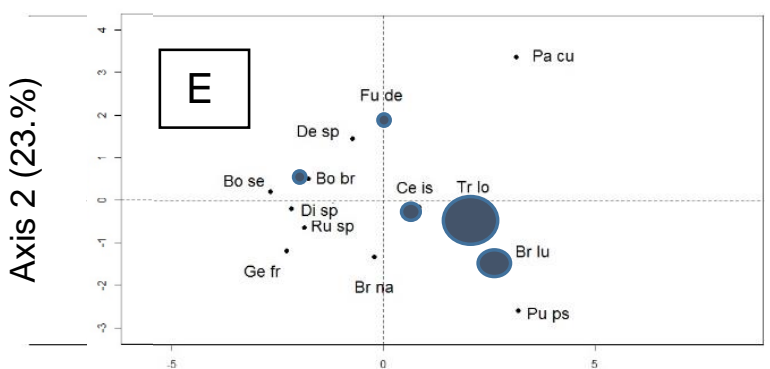

Axis $1(43 \%)$

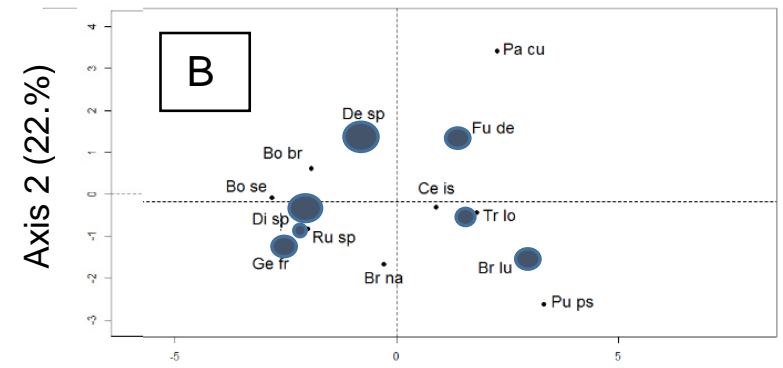

Axis 1 (44\%)

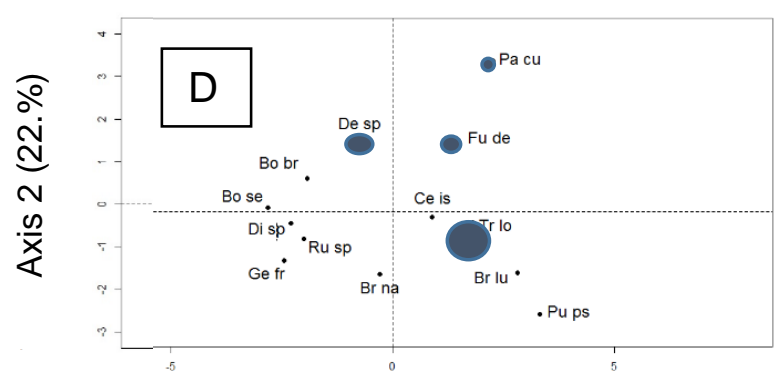

Axis 1 (44\%)

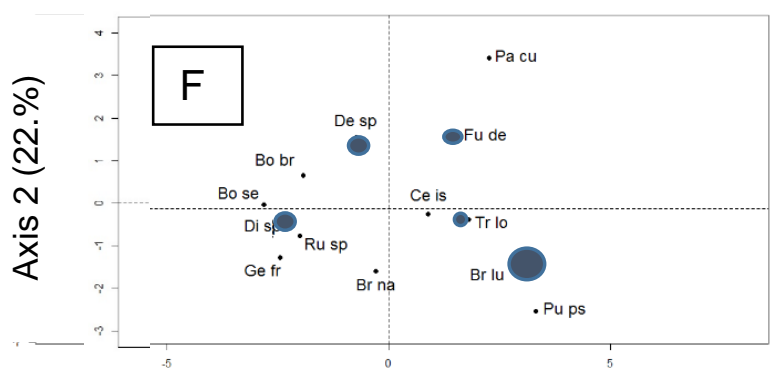

Axis $1(44 \%)$ 
Table 3. Total visitation recorded by the most connected species in the bird-flowering plant visitation network.

\begin{tabular}{lrrrrrr} 
Plant species/Bird visitor & \multicolumn{2}{c}{ Metaltail } & \multicolumn{2}{c}{ Sapphirewing } & \multicolumn{2}{r}{ Flowerpiercer } \\
Season & Dry & Wet & Dry & Wet & Dry & Wet \\
Bomarea brevis & 7 & 0 & 0 & 0 & 1 & 0 \\
Bomarea setacea & 5 & 0 & 0 & 0 & 0 & 0 \\
Brachyotum lutescens & 42 & 3 & 0 & 0 & 6 & 4 \\
Brachyotum naudinii & 7 & 0 & 0 & 0 & 0 & 0 \\
Centropogon isabellinus & 1 & 0 & 0 & 0 & 2 & 0 \\
Desfontainia spinosa & 3 & 4 & 0 & 2 & 0 & 1 \\
Disterigma sp & 4 & 1 & 0 & 0 & 0 & 1 \\
Fuchsia decussata & 7 & 3 & 1 & 2 & 1 & 1 \\
Gentianella fruticulosa & 0 & 3 & 0 & 0 & 0 & 0 \\
Passiflora cumbalensis & 3 & 0 & 1 & 1 & 0 & 0 \\
Puya pseudoeryngioides & 1 & 0 & 0 & 0 & 0 & 0 \\
Rubus sp. & 6 & 4 & 0 & 0 & 0 & 0 \\
Tristerix longebracteatus & 2 & 2 & 23 & 15 & 14 & 1 \\
\hline
\end{tabular}

288

289

290

291

292

293

294

295

296

297

298

299

300

301

302

303

304

305

306

307

308

309

Table 4. Spearman correlation coefficients for bird visitation against nectar traits (axis 1) and corolla morphology (axis 2) of the principal component analysis for flowering plants visited by birds in the elfin forest.

\begin{tabular}{lllll}
\hline Season & Dry & \multicolumn{3}{l}{ Wet } \\
\hline Axis & 1 & 2 & 1 & 2 \\
Pterophanes cyanopterus & 0.435 & $0.547^{*}$ & 0.339 & $0.595^{\star}$ \\
Diglossa mystacalis & 0.398 & 0.069 & 0.271 & 0.089 \\
\hline
\end{tabular}

${ }^{\star} \mathrm{P}=<0.05$

\section{Plant Trait Variability}

The abundance of flowers and number of species flowering varied across seasons (Figure 3). Plants that flowered across seasons included Bomarea brevis, Brachyotum lutescens, Tristerix longebracteatus, Fuchsia decussata and Rubus sp., while Centropogon isabellinus and Bomarea setacea produced flowers for only limited periods. Puya was spatially patchy and flowered only over a short period of time in the wet season. Some species, such as Brachyotum naudinii and Bomarea setacea, also flowered only in the wet season.

The factors of flower aggregation, corolla color, and flower orientation were not independent; they were linked to specific species of plants that the birds visited, so there is no way to account for floral selectivity based on these factors. Flowers of Tristerix longebracteatus, which are red, were visited by the Sapphirewing and the Flowerpiercer, but not by the Metaltail (Table 3). The three birds visited species of plants that had many flowers per individual ( $B$. lutescens and $T$. longebracteatus); but differed in the orientation of the flowers they foraged. The Metaltail visited mostly the 
pendular flowers of $B$. lutescens; the Sapphirewing and the Flowerpiercer frequented horizontals of $T$. longebracteatus. The Sapphirewing foraged almost exclusively in the tree canopy, the Metaltail mostly in the understory, and the flowerpiercer was between the canopy and the understory (Sup.Table 1).

Bomarea brevis

Bomarea setacea

Brachyotum lutescens

Brachyotum naudini

Centropogon isabellinus

Desfontainea spinoza

Disterigma $\mathrm{sp}$

Fuchsia decussata

Gentianella fruticulosa

Passiflora cumbalensis

Puya pseudoeryngioides

Rubus sp

Tristerix longibracteatus

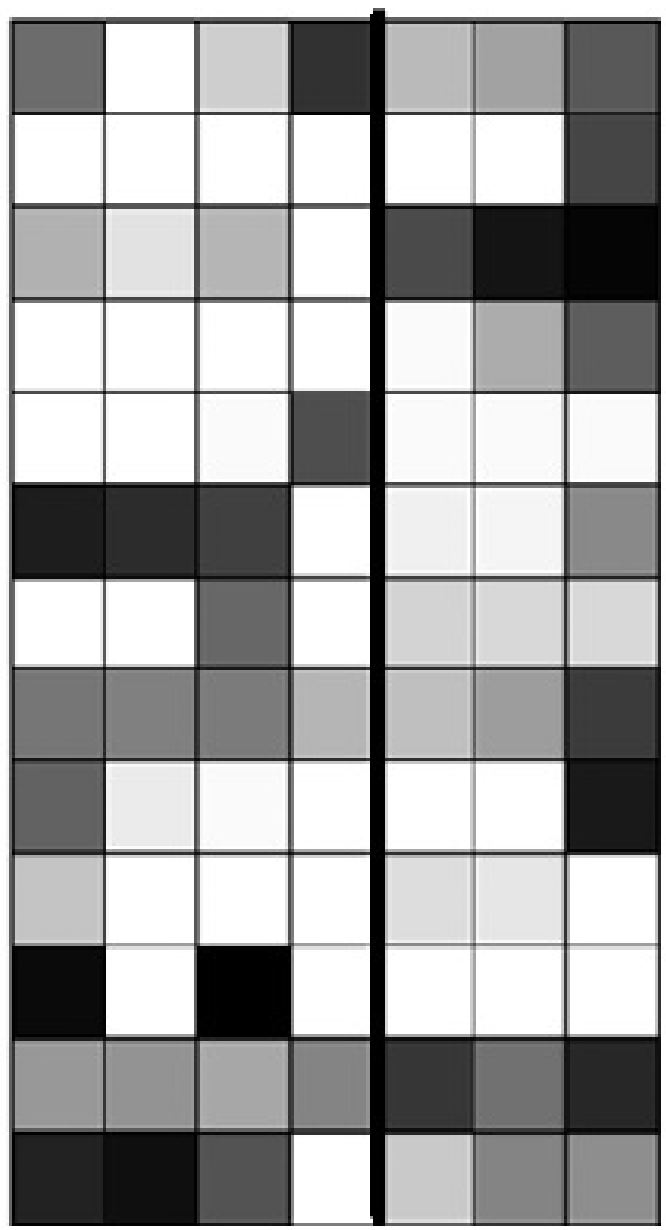

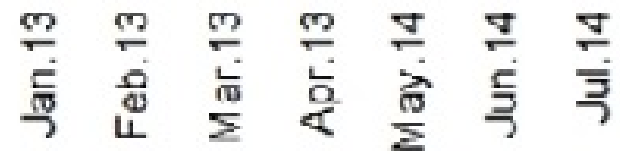

\section{Wet Season Dry Season}

315
Figure 3. Flowering phenologies of ornithophilus plants most visited by birds in the elfin forest (2013-2014). The darker the square, the higher the number of flowers per hectare.

As expected, the nectar volume and concentration varied considerably among the plant species selected. I reported the information for the plants that had nectar 
(Table 2). Several of these species had less than $50 \%$ of their flowers with nectar (Figure 4). Further, nectar volume and concentration were also found to vary between dry and wet season for Fuchsia decussata, Passiflora cumbalensis and Tristerix longebracteatus; all three of these species had long corollas. Passiflora cumbalensis had the highest energy available per flower $(5.39 \pm 2.66 \mathrm{mg})$ and highest concentration (19.54 \pm 5.81 ), followed by Puya pseudoeryngioides, Fuchsia decussata and Brachyotum lutescens. Brachyotum lutescens had higher average nectar volume, followed by Puya $(36.39 \pm 16.84 \mu \mathrm{l})$.

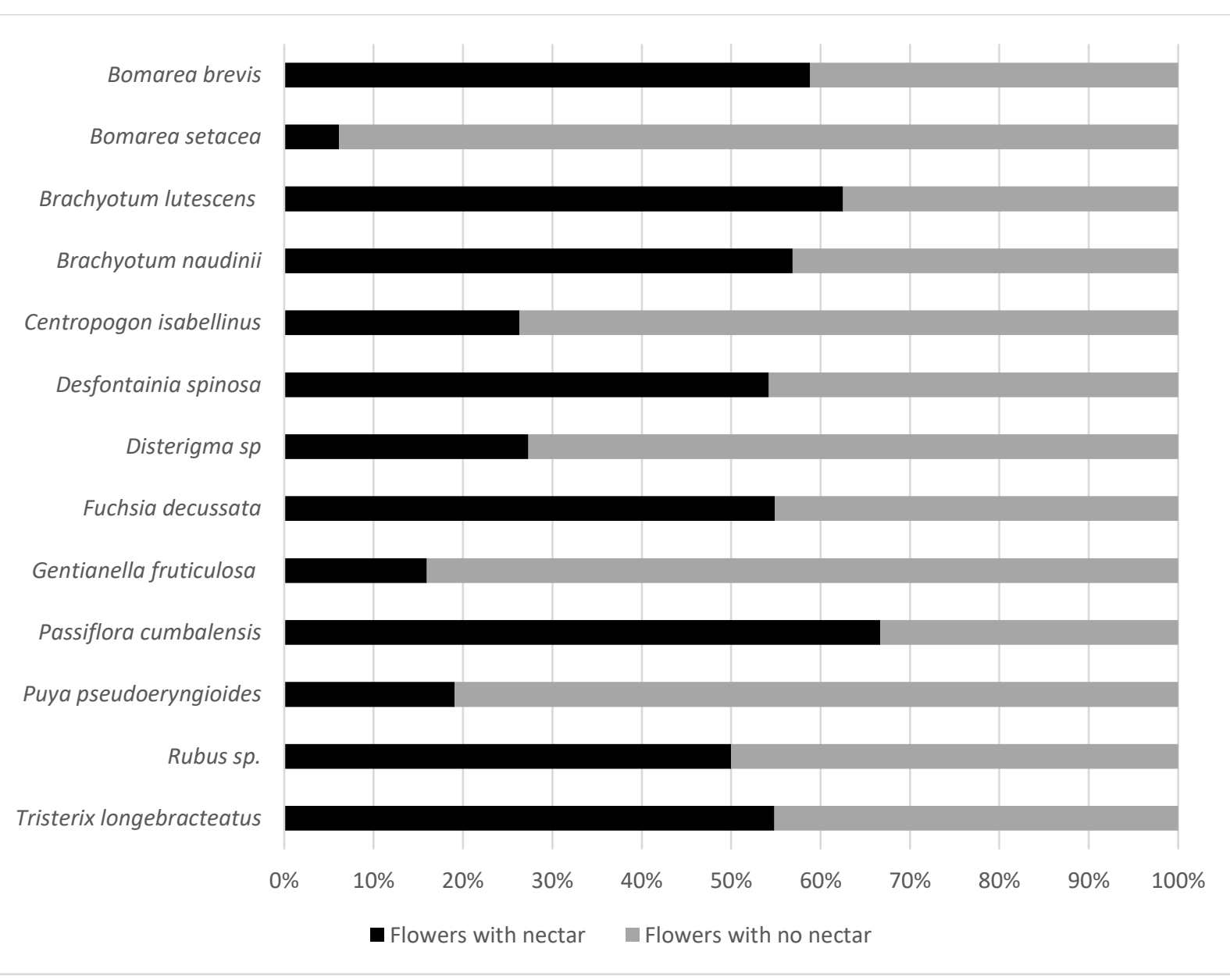

Figure 4. Nectar availability in flowers of plants most visited by birds in the elfin forest.

\section{Discussion}

Plant species of elfin forests can be separated based on nectar and morphological traits (Figure 1). Half or more of the bird visits to flowers for the Metaltail, the Sapphirewing, and the Flowerpiercer were focused on plants with higher scores along the first PCA axis in the dry season (Figure 2). I expected that plants with higher energy rewards, as indicated by nectar volume and sugar concentration, would be more attractive to birds. However, this expectation held only for the Metaltail in the dry 
season. I found no significant association between visitation and scores along the first PCA axis, which was defined mainly by nectar rewards, for either Sapphirewings or flowerpiercers (Table 4). As the first PCA axis only captured $43-44 \%$ of the total variation, there may be other factors that are needed to explain bird visits as a function of floral characters. For bird visitors of Rhododendron flowers in the Himalayas, long corollas and high nectar volume are the main preferences (Basnett et al. 2019).

Plants that had both large nectar rewards and larger number of flowers per plant were the shrub Brachyotum lutescens and the mistletoe Tristerix longebracteatus. Both were frequently visited by these birds (Gonzalez and Loiselle 2016) and other nectarivorous birds in similar ecosystems, such as the elfin forest in the Colombian paramo (Gutierrez and Rojas 2001). The PCA separated plants that were more insectpollinated than bird-pollinated; the former plants have low nectar reward and short corollas. For these plants (e.g. Disterigma spp., Gentianella fruticulosa, Bomarea spp., Rubus, Figure 2), the Metaltail was the more important bird visitor among those studied here (Gonzalez and Loiselle 2016).

Usually, small hummingbirds, such as the Metaltail, are generalists in terms of flower visitation while large hummingbirds like the Sapphirewing are specialists (Dalsgaard et al. 2009). The different plant species that the Metaltail and the Sapphirewing used as resources are in part similar to two of the groups of plants and hummingbirds identified by Gutierrez et al. (2004) in an elfin forest of Colombia. Small, short billed-hummingbirds tend to visit plants with a low nectar reward while large hummingbirds visit plants that have long-corolla flowers. Metaltails showed significant associations with flower characteristics along both PCA axes, which largely reflect floral rewards and flower size. Although the abundance and phenology of flowering plants varied between seasons (Fig. 3), the plant trait ordination was almost identical in both seasons (Sup. Table 1).

The Sapphirewing visited Tristerix longebracteatus as its primary floral resource in both dry and wet season. Other plants which had higher nectar volume and sugar content (e.g. Puya pseudoeryngioides, Table 2) were not visited by this bird. This result suggests that Sapphirewings might have been selecting certain plant species (e.g., Tristerix) rather than general plant characteristics (e.g., high energy rewards). In an elfin forest of Colombia, Sapphirewings visited primarily one Puya species, and such visits may be associated with plant phenology (i.e., what plants are available when birds are present) (Gutierrez et al. 2004).

The Flowerpiercer, like the Metaltail, was a generalist but tended to visit plants with high nectar reward and high number of flowers per plant, such as Brachyotum lutescens and Tristerix longebracteatus. Other species of Diglossa also are known to visit Brachyotum (Stiles et al. 1992) or Tristerix longebracteatus (Graves 1992). The peculiar foraging behavior of the Flowerpiercer, searching for the flowers that are on a different spatial level than flowers commonly used by hummingbirds (Feinsinger and Cowell 1978), might explain coexistence with the other two hummingbird species that use the same nectar resources. The different patterns of visitation to plants by these three bird species between seasons may be related to change in floral preferences over time (Fagua and Gonzalez 2007).

The fact that no statistical associations were detected between bird visitation and plant traits for the Metaltail in the wet season, the Sapphirewing in the dry season and 
the Flowerpiercer in both seasons (Table 4), suggest that other factors beyond floral traits may be needed to explain patterns of floral visitation by birds. Future studies should examine in greater detail specific preferences of bird species for plant species using controlled experiments (Maglianesi et al. 2015, Fenster et al. 2015).

\section{ACKNOWLEDGEMENTS}

395

396

397

398

399

400

401

402

403

404

405

406

407

408

409

410

I thank Dr. Bette Loiselle for her guidance in this research. I also thank the field assistants that helped in taking several measurements of plant traits and bird visits to the plants: mainly from the Universidad de Huanuco. Funding for fieldwork in Peru came from the Premio Nacional para la Investigacion Ambiental of the Ministerio del Ambiente of Peru, Optics for the Tropics, Royal Society for Bird Protection, Idea Wild and University of Florida's Tropical Conservation and Development Program field research fund. Research Grant. Thanks to FINCyT in Peru and WWF for funding my PhD studies.

\section{LITERATURE CITED}

Abrahamczyk, S., J. Kluge, Y. Gareca, S.Reichle and M. Kessler. 2011. The Influence of Climatic Seasonality on the Diversity of Different Tropical Pollinator Groups. PLOS ONE 6.

Abrahamczyk, S., and M. Kessler. 2015. Morphological and behavioural adaptations to feed on nectar: how feeding ecology determines the diversity and composition of hummingbird assemblages. Journal of Ornithology 156:333-347.

Aizen, M. A. 2003. Down-facing flowers, hummingbirds and rain. Taxon 52:675-680.

Ayala, A. V. 1986. Aspects of the relationship between Thalurania furcate colombica (Aves: Trochilidae) and the flowers from which it sucks in a sub-andean forest. Caldasia 14:549-562.

Baker, H. G. 1975. Sugar concentrations in nectars from hummingbird flowers. Biotropica 7:37-41.

Basnett, S., R. Ganesan, and S.M. Devy. 2019. Floral traits determine pollinator visitation in Rhododendron species across an elevation gradient in the Sikkim Himalaya. Alpine Botany 129:81-94.

Bolten, A. B., P. Feinsinger, H. G. Baker, and I. Baker. 1979. Calculation of sugar concentration in flower nectar. Oecologia 41:301-304.

Bourgault, P., D. Thomas, P. Perret, and J. Blondel. 2010. Spring vegetation phenology is a robust predictor of breeding date across broad landscapes: a multi-site approach using the Corsican blue tit (Cyanistes caeruleus). Oecologia 162:885892. 
Cotton, P. A. 2007. Seasonal resource tracking by Amazonian hummingbirds. Ibis 149: 135-142.

Cruden, R. W. 1972. Pollinators in high-elevation ecosystems - relative effectiveness of birds and bees. Science 176:1439-1440.

Cruden, R. W., and S. M. Hermann. 1983. Studying nectar? Some observations on the art. Pages 223-241 in Bentley, B and T. Elias, editors. The Biology of Nectaries. University of Columbia Press. New York. USA.

Cruden, R. W., S. M. Herman, and S. Peterson. 1983. Patterns of nectar production and plant-pollinator coevolution. Pages 80-125 in Bentley, B and T. Elias, editors. The Biology of Nectaries. University of Columbia Press. New York. USA.

Dafni, A. 1992. Pollination Ecology. A Practical Approach. Oxford University Press. New York. USA.

Dalsgaard, B., A. M. M. Gonzalez, J. M. Olesen, J. Ollerton, A. Timmermann, L. H. Andersen, and A. G. Tossas. 2009. Plant-hummingbird interactions in the West Indies: floral specialisation gradients associated with environment and hummingbird size. Oecologia 159:757-766.

Dante, S. K., B. S. Schamp, and L. W. Aarssen. 2013. Evidence of deterministic assembly according to flowering time in an old-field plant community. Functional Ecology 27:555-564.

Davis, A., R. E. Major, and C. E. Taylor. 2015. The association between nectar availability and nectarivorous density in urban and natural environments. Urban Ecosystems 18:503-515.

Dudash, M. R., C. Hassler, P. M. Stevens, and C. B. Fenster. 2011. Experimental floral and inflorescence trait manipulations affect pollinator preference and function in a hummingbird-pollinated plant. American Journal of Botany 98:275-282.

Dunning, J. B., Jr. 2007. CRC handbook of avian body masses. 2nd ed. CRC, Boca Raton, FL. USA.

Fagua, J. C., and V. H. Gonzalez. 2007. Growth rates, reproductive phenology, and pollination ecology of Espeletia grandiflora (Asteraceae), a giant Andean caulescent rosette. Plant Biology 9:127-135.

Feinsinger, P. 1976. Organization of a tropical guild of nectarivorous birds. Ecological Monographs 46:257-291.

Feinsinger, P. 1980. Asynchronous migration patterns and the coexistence of tropical hummingbirds. Pages 411-419 in Keast, A., and E. Morton, editors. Migrant bird in the Neotropics: ecology, behavior, distribution and conservation. Smithsonian Institution Press, Washington D.C. USA. 
Feinsinger, P., and R. K. Colwell. 1978. Community organization among neotropical nectar-feeding birds. American Zoologist 18:779-795.

Fenster, C. B. 1991. Selection on floral morphology by hummingbirds. Biotropica 23:98101.

Fenster, C. B., R. J. Reynolds, C. W. Williams, R. Makowsky, and M. R. Dudash. 2015. Quantifying hummingbird preference for floral trait combinations: The role of selection on trait interactions in the evolution of pollination syndromes. Evolution 69:1113-1127.

Fleming, P. A., B. H. Bakken, C. N. Lotz, and S. W. Nicolson. 2004. Concentration and temperature effects on sugar intake and preferences in a sunbird and a hummingbird. Functional Ecology 18:223-232.

Fonturbel, F.E., P. Jordano, and R. Medel. 2015. Scale-dependent responses of pollination and seed dispersal mutualisms in a habitat transformation scenario. Journal of Animal Ecology 103:1334-1343.

Gonzalez, O. 2008. Aves de la Selva Central Peruana: Levantamiento de informacion ornitologica del Parque Nacional Yanachaga-Chemillen. Technical Report submitted to the Office of Natural Protected Areas, INRENA. PROFONANPE. Lima. Peru.

Gonzalez, O., and B. Loiselle. 2016. Bird-flowering plant network in the Andes: phenology is more important than abundance or morphology. PeerJ 4:e2789. floral resources in an elfin forest of the central Andes of Peru. Ecologia Aplicada 18(1):21-35.

Gutiérrez, A., and S. Rojas. 2001. Dinámica anual de la interacción colibrí-flor en ecosistemas altoandinos del volcán Galeras, sur de Colombia. Tesis de grado, Universidad Nacional de Colombia, Bogotá. Colombia. hummingbird-flower interactions in high Andean ecosystems. Ornitologia Neotropical 15 (Suppl.): 205-213.

Gutierrez-Zamora, A. 2008. Ecological interactions and structure of a high Andean community of hummingbirds and flowers in the Eastern Andes of Colombia. Ornitologia Colombiana 7:17-42.

494 Hainsworth, F. R., and L. L. Wolf. 1976. Nectar characteristics and food selection by hummingbirds. Oecologia 25:101-113. 
496

497

498

499

500

501

502

503

504

505

506

507

508

509

510

511

512

513

514

515

516

517

518

519

520

521

522

523

524

525

526

527

528

529

530

Handelman, C., and J. R. Kohn. 2014. Hummingbird color preference within a natural hybrid population of Mimulus aurantiacus (Phrymaceae). Plant Species Biology 29:65-72.

Inouye, D. W., W. A. Calder, and N. M. Waser. 1991. The effect of floral abundance on feeder censuses of hummingbird populations. Condor 93:279-285.

Janecek, S., J. Riegert, O. Sedlacek, M. Bartos, D. Horak, J. Reif, E. Padysakova, D. Fainova, M. Antczak, M. Pesata, V. Mikes, E. Patacova, J. Altman, et al. 2012. Food selection by avian floral visitors: an important aspect of plant-flower visitor interactions in West Africa. Biological Journal of the Linnean Society 107:355367.

Justino, D. G., P. K. Maruyama, and P. E. Oliveira. 2012. Floral resource availability and hummingbird territorial behaviour on a Neotropical savanna shrub. Journal of Ornithology 153:189-197.

Kearns, C.A. and D.A. Inouye. 1993. Techniques for Pollination Biologists. University Press of Colorado. USA.

Kodric-Brown, A., J. H. Brown, G. S. Byers, and D. F. Gori. 1984. Organization of a tropical island community of hummingbirds and flowers. Ecology 65:1358-1368.

Lê, S., Josse, J. and F. Husson. 2008. FactoMineR: An R Package for Multivariate Analysis. Journal of Statistical Software 25(1):1-18.

Maglianesi, M.A., N. Blüthgen, K. Boehning-Gaese, and M. Schleuning. 2014. Morphological traits determine specialization and resource use in planthummingbird networks in the neotropics. Ecology 95:3325-3334.

Maglianesi, M. A., K. Bohning-Gaese, and M. Schleuning. 2015. Different foraging preferences of hummingbirds on artificial and natural flowers reveal mechanisms structuring plant-pollinator interactions. Journal of Animal Ecology 84:655-664.

Maloof, J. E., and D. W. Inouye. 2000. Are nectar robbers cheaters or mutualists? Ecology 81:2651-2661.

Martinez del Rio, C. M., and L. E. Eguiarte. 1987. Bird visitation to Agave salmiana comparisons among hummingbirds and perching birds. Condor 89:357-363.

Maruyama, P. K., J. Vizentin-Bugoni, G. M. Oliveira, P. E. Oliveira, and B. Dalsgaard. 2014. Morphological and spatio-temporal mismatches shape a neotropical savanna plant-hummingbird network. Biotropica 46:740-747.

McDade, L. A., and J. A. Weeks. 2004a. Nectar in hummingbird-pollinated neotropical plants I: Patterns of production and variability in 12 species. Biotropica 36:196215. 
McDade, L. A., and J. A. Weeks. 2004b. Nectar in hummingbird-pollinated neotropical plants II: Interactions with flower visitors. Biotropica 36:216-230.

533

534

535

536

537

538

539

540

541

542

543

544

545

546

547

548

549

550

551

552

553

554

555

556

557

558

559

560

561

562

563

564

565

566

McKinney, A. M., P. J. CaraDonna, D. W. Inouye, B. Barr, C. D. Bertelsen, and N. M. Waser. 2012. Asynchronous changes in phenology of migrating Broad-tailed Hummingbirds and their early-season nectar resources. Ecology 93:1987-1993.

Murcia C. 1996. Forest fragmentation and the pollination of Neotropical plants. Pages 19-36 in Schelhas J. and R.Greenberg, editors. Forest Patches in Tropical Landscapes. Island Press, Washington DC. USA.

Nicolson, S. W., and P. A. Fleming. 2003. Nectar as food for birds: the physiological consequences of drinking dilute sugar solutions. Plant Systematics and Evolution 238:139-153.

Opler, P. A. 1983. Nectar production in a tropical ecosystem. Pages 30-79 in Bentley B. and T. Elias, editors. The biology of nectaries. Columbia University Press. New York. USA.

Ornelas, J. F., M. Ordano, A. J. De-Nova, M. E. Quintero, and T. Garland, Jr. 2007. Phylogenetic analysis of interspecific variation in nectar of hummingbird-visited plants. Journal of Evolutionary Biology 20:1904-1917.

Ortiz-Pulido, R., and C. L. Rodriguez. 2011. Is energy in nectar a good predictor of hummingbird activity at landscape scale? Italian Journal of Zoology 79:100-104.

Ortiz-Pulido, R., and G. Vargas-Licona. 2008. Exploring the relationship between hummingbird records and flower abundance with spatio-temporal scaling. Ornitologia Neotropical 19:473-483.

Ramirez, O., M. Arana, E. Bazan, A. Ramirez and A. Cano. 2007. Assamblages of two mammal and bird communities in two major ecological units in the high Andean plateau of southern Peru. Ecologia Aplicada 6(1-2):1-15.

Rathcke, B. J. 1992. Nectar distributions, pollinator behavior, and plant reproductive success. Pages 113-138 in M. D. Hunter, T. Ohgushi, and P. W. Price, editors. Effects of resource distribution on animal-plant interactions. Academic Press, San Diego. USA.

Rodriguez-Flores, C.I., F.G.Stiles and M.C. Arizmendi. 2012. Pollination network of a hermit hummingbird community (Trochilidae, Phaethornithinae) and their nectar resources in the Colombian Amazon. Ornitologia Neotropical 23:85-100.

Rotenberry, J. T. 1990. Variable floral phenology - temporal resource heterogeneity and its implication for flower visitors. Holarctic Ecology 13:1-10.

Schmid, B., H. Nottebrock, K. J. Esler, J. Pagel, A. Pauw, K. Boehning-Gaese, F. M. Schurr, and M. Schleuning. 2015. Reward quality predicts effects of bird- 
pollinators on the reproduction of African Protea shrubs. Perspectives in Plant Ecology Evolution and Systematics 17:209-217.

Schuchmann, K.L. 1999. Hummingbirds. Pages 468-680 in Del Hoyo, J. Elliot, A. and Sargatal, J. editors. Handbook of the birds of the world. Vol. 5. Barn owls to Hummingbirds. Lynx Editions, Barcelona. Spain.

Stiles, F. G. 1978. Temporal organization of flowering among hummingbird foodplants of a tropical wet forest. Biotropica 10(3):194-210.

Stiles, F. G. 1980. The annual cycle in a tropical wet forest hummingbird community. Ibis 122:322-343.

Stiles, F. G. 1985. Seasonal patterns and coevolution in the hummingbird-flower community of a Costa Rican subtropical forest. Ornithological Monographs 36:757-787.

Stiles, G., A. Ayala and M. Girón. 1992. Polinizacion de las flores de Brachyotum (Melastomataceae) por dos especies de Diglossa (Emberizidae). Caldasia $17(1): 47-54$.

Stiles, F. G., and C. E. Freeman. 1993. Patterns in floral nectar characteristics of some bird-visited plant-species from Costa-Rica. Biotropica 25:191-205.

Sutherland, G. D., and C. L. Gass. 1995. Learning and remembering of spatial patterns by hummingbirds. Animal Behaviour 50:1273-1286.

Temeles, E. J., Y. B. Linhart, M. Masonjones and H. D. Masonjones. 2002. The role of flower width in hummingbird bill length-flower length relationships. Biotropica 34:68-80.

Toloza-Moreno, D.L., D.A. León-Camargo and L. Rosero-Lasprilla 2014. Annual cycle of hummingbirds (Trochilidae) in high Andean forests and paramo areas of the Cordillera Oriental of Colombia. Ornitología Colombiana 14: 28-47.

Vizentin-Bugoni, J., P. K. Maruyama, and M. Sazima. 2014. Processes entangling interactions in communities: forbidden links are more important than abundance in a hummingbird-plant network. Proceedings of the Royal Society B-Biological Sciences 281 .

Wiens, J. A. 1989. The ecology of bird communities. Volume 2: processes and variation. Cambridge University Press. New York. USA.

Willmer, P. 2011. Pollination and Floral Ecology. Princeton University Press. USA.

Wilson, P., M. C. Castellanos, A. D. Wolfe, and J. D. Thomson. 2006. Shifts between bee and bird pollination in penstemons. Pages 47-68 in N.M. Waser and J. 
Ollerton, editors. Plant-pollinator interactions: from specialization to

603 Wolf, L. L., F. G. Stiles, and F. R. Hainsworth. 1976. Ecological organization of a

604

605 tropical, highland hummingbird community. Journal of Animal Ecology 45:349379.

606 Zambon V., K. Agostini, M. Nepi, M.L. Rossi, A.P. Martinelli, and M. Sazima. The role of nectar traits and nectary morphoanatomy in the plant-pollinator interaction between Billbergia distachia (Bromeliaceae) and the hermit Phaethornis

610 Zuur, A.F., Leno, E.N., Walker, N.J., Saveliev, A.A., and Smith, G.M. 2009. Mixed effects models and extensions in ecology with R. Springer, New York. USA. 
613 Supplementary Table 1. Principal component analysis for the plant traits that are 614 visited by the most connected birds in the bird-flowering plant visitation network.

\begin{tabular}{|c|c|c|c|c|}
\hline & \multicolumn{2}{|l|}{ Dry Season } & \multicolumn{2}{|l|}{ Wet Season } \\
\hline & Axis 1 & Axis 2 & Axis 1 & Axis 2 \\
\hline Eigenvalue & 4.328 & 2.296 & 4.445 & 2.168 \\
\hline$\%$ of var. & 43.276 & 22.959 & 44.445 & 21.678 \\
\hline Cumulative $\%$ of var. & 43.276 & 66.235 & 44.445 & 66.123 \\
\hline PC1 & correlation & $p$ value & correlation & $p$ value \\
\hline Max nectar & 0.941 & * & 0.940 & \\
\hline Nectar per flower & 0.940 & * & 0.955 & \\
\hline Milligrams sugar per flower & 0.886 & * & 0.906 & \\
\hline Maximum nectar concentration & 0.823 & * & 0.774 & \\
\hline Flowers per individual & 0.623 & 0.02 & 0.676 & 0.01 \\
\hline Height of flowers & 0.508 & 0.07 & 0.525 & 0.11 \\
\hline Corolla length & 0.446 & 0.12 & 0.456 & 0.11 \\
\hline C.V. Milligrams sugar per flower & 0.379 & 0.2 & 0.459 & 0.11 \\
\hline C.V. Microliters nectar per flower & 0.152 & 0.6 & 0.126 & 0.68 \\
\hline Corolla width & -0.287 & 0.3 & -0.246 & 0.41 \\
\hline PC2 & & & & \\
\hline Corolla length & 0.849 & * & 0.844 & \\
\hline Heigh & 0.661 & 0.01 & 0.629 & 0.02 \\
\hline Flowers per individual & -0.619 & 0.02 & -0.632 & 0.02 \\
\hline Corolla width & 0.524 & 0.06 & 0.553 & 0.04 \\
\hline oncentration & 0.291 & 0.33 & 0.337 & 0.25 \\
\hline yar per flower & 0.201 & 0.50 & 0.095 & 0.75 \\
\hline Maximum nectar concentration & -0.164 & 0.59 & -0.163 & 0.59 \\
\hline C.V. Microliters nectar per flower & -0.222 & 0.46 & -0.251 & 0.40 \\
\hline Nectar per flower & -0.246 & 0.41 & -0.169 & 0.58 \\
\hline C.V. Milliarams sugar per flower & -0.465 & 0.10 & -0.334 & 0.26 \\
\hline
\end{tabular}

